Vol. 8, No. 2, 2021

https://doi.org/10.23939/eem2021.02.017

UDC 614.2: 331.5

JEL Classification Code: I18, J82

Natalia Dochynets

Transcarpathian Academy of Arts, Ukraine, PhD, Associate Professor

E-mail: natalya.dochynets@gmail.com

ORCID ID: 0000-0002-7075-8760

Olesya Havrylets

Mukachevo State University, Ukraine, PhD, Associate Professor

E-mail: gavrilec2017@gmail.com

ORCID ID: 0000-0001-7333-0041

Heorhina Kampo

Uzhgorod National University, Ukraine, PhD, Associate Professor

E-mail: heorhina.kampo@uzhnu.edu.ua

ORCID ID: 0000-0002-3131-8607

\title{
ON THE PROBLEM OF HUMAN RESOURCES IN UKRAINIAN PRIVATE HEALTH CARE
}

\begin{abstract}
The article is devoted to the scientific analysis of human resources in the healthcare system of Ukraine, particularly in the private sector. The study is specifically concerned with the current staffing of the healthcare system of Ukraine with doctors and junior specialists with medical education. We analyzed the ratio of the main quantitative indicators of medical workforce in healthcare institutions of different forms of ownership, as well as the dynamics of indicators representing involvement of doctors of different specialties in the private healthcare practice. Acute issues concerning workforce in the private healthcare sector were identified and analysed, with a matter of pressing concern being inferior quality of professional training provided for medical staff. This research was aimed at substantiating the role of the state human resource policy in healthcare system and examining the political measures taken by the government in order to develop medical education and science, and to increase healthcare workforce potential. Conclusively, we formulated proposals regarding appropriate solutions to the human resource problems of the private healthcare service providers in Ukraine.

Key words: staffing, healthcare services, healthcare institution (HCI), private health care, medical workers, doctors, middle medical staff.
\end{abstract}

\section{Statement of the problem}

To increase the effectiveness of economic competition government should use not only controlling but also stimulating tools, the most important among which is the workforce supply for different sectors of the economy. One of such sectors is health care, especially, its private part, which significantly affects the competitive environment of the healthcare sector in the context of its reform.

\section{The actuality of the research}

Scientists and practitioners talk about the benefits of private health care. In our opinion, two main ones are to be highlighted: firstly, private institutions relieve the burden on public hospitals and clinics (especially during the COVID-19 pandemic), which has a positive impact on the healthcare system, and even saves it; secondly, thanks to the private healthcare services providers, the consumer has received an alternative and can exercise the right of consumer choice. Thus, 
customer focus, availability, and efficiency of medical services, quality equipment, and facilities are the benefits that public healthcare institutions, as opposed to the private sector, are currently unable to offer to the patient.

Today we witness the development of private health care market. The crisis of public health care, the imperfection of its reform, chronic lack of budget funding for public health programs, as well as growing domestic demand for medical services due to pandemic of COVID-19 catalyzes the growth of private healthcare facilities in both highly urbanized areas of the country and small towns. According to experts, the share of the private medical market in health care in Ukraine is $10-15 \%$ (according to the World Bank and the EBRD - up to $4 \%$ ). For comparison, in 2012 it was only $1 \%$.

Despite some positive market trends, some factors hinder the further development of the private medical market. Among the main ones is the problem of staffing in the healthcare market. It is especially relevant for the private sector, as there are higher requirements for professional training than in public healthcare facilities. All these factors determine the actuality of this research within the context of the competition policy which is currently formed in the sphere of health care.

\section{Analysis of recent research and publications}

Due to the importance of meeting the vital needs and ensuring the socio-economic stability of the state and society as a whole, health care is the object of attention of many scientists and practitioners. A significant role in the study of the problems of human resource supply in health care belongs to O. Gutsalyuk, who proposes some approaches to staffing the health care sector of Ukraine during the reformation of the industry [2]. O. Volosovets, V. Zabolotko, A. Volosovets analyze the current staffing of health care institutions in Ukraine and compare it with the world and European indicators [3]. I. Mazur, K. Naduty, A. Ananieva analyze the human resource potential of health care in Ukraine [4]. O. Limeshko studies the peculiarities of the medical staff recruitment procedure in Ukraine [5] etc.

It should be noted that researchers of the workforce in health care mainly analyze the staffing in the national health care sector in general. However, facing the importance of the private healthcare sector for the progress of this industry, we need to focus on the problem of the workforce supply of private healthcare providers.

\section{Setting goals and objectives}

The current study aims to analyze human resources supply in Ukrainian private health care. To achieve the goal we need:

- to consider the workforce supply of the healthcare system of Ukraine with doctors and middle medical staff, in particular, to analyze the ratio of the main quantitative indicators of medical workers supply in the healthcare providers of different forms of ownership;

- to determine the current problems of staffing the market of private health care, to analyze the dynamics of indicators of involvement in the private medical practice of doctors of different specialties;

- to consider the main measures of state policy in medical education, science, and development of medical personnel;

- to propose the solution to problems of staffing of the private health care clinics in Ukraine.

\section{Presentation of the results}

Medical personnel is an important strategic capital of the state. About $70 \%$ of all healthcare investments in the world go to human resources.

The staffing situation in the healthcare sector of Ukraine has deteriorated significantly over the last decade. According to the Center for Medical Statistics of the Ministry of Health of Ukraine, by the end of 2020, medical care in health care facilities of all forms of ownership had been provided by 488.360 medical workers, of which 179.602 were doctors of all specialties and 308.758 middle medical workers $[6$, p. 55]. Over 10 years, the number of working doctors decreased by 45.274 person $(-20 \%)$, and middle medical workers - by 158 thousand person (-33.9\%) (Fig. 1).

In recent years, a steady trend towards the decreasing the number of nationally trained medical personnel in Ukraine has been observed. Since 2014 , the health care sector has lost an average of 12.744 health workers per year (Table 1). 
On the problem of human resources in ukrainian private health care

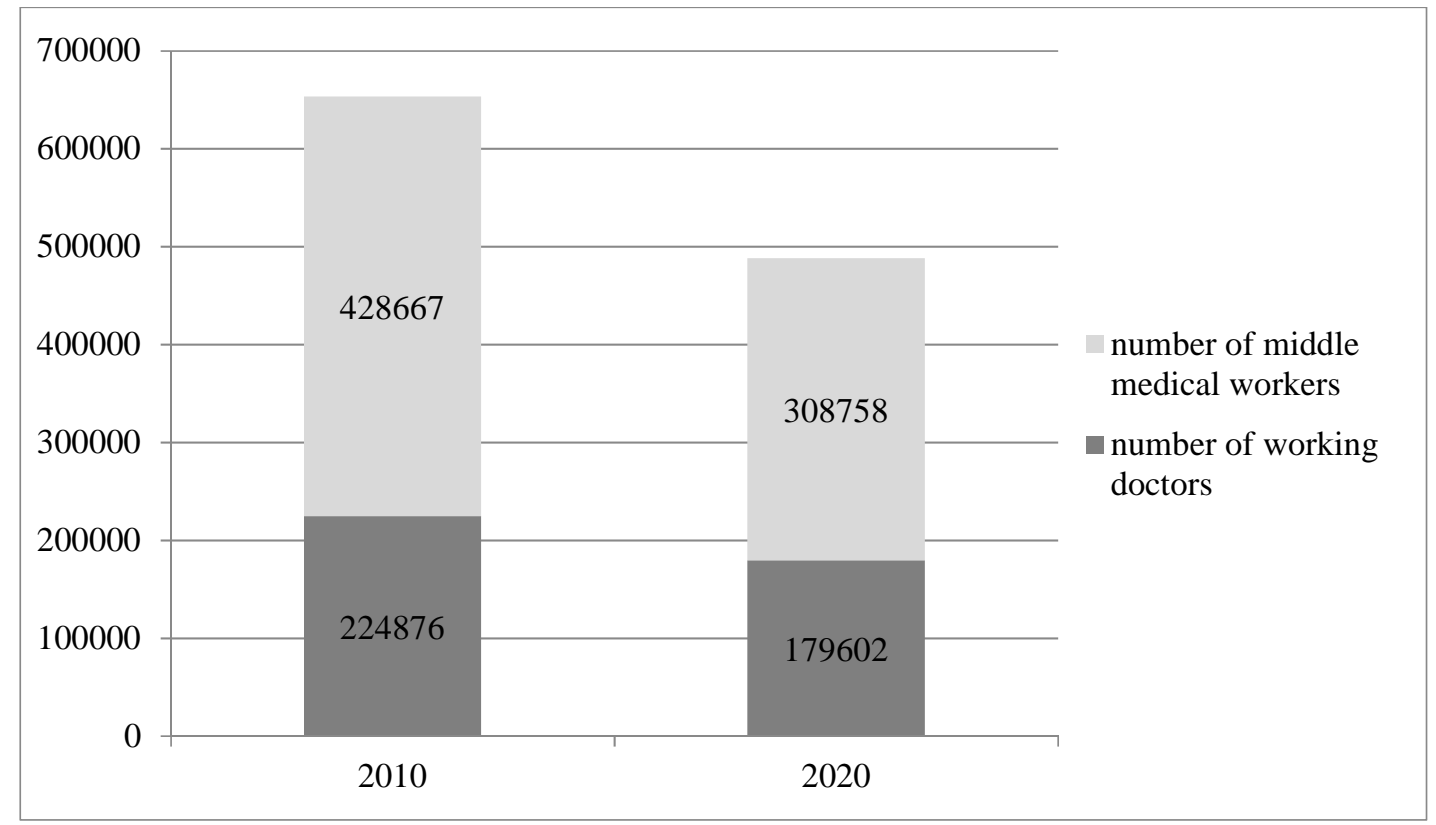

Fig. 1. Comparative analysis of the number of medical workers in Ukraine in 2010 and 2020

Source: Based on the data of the statistical reference book of the Center for Medical Statistics of the Ministry of Health of Ukraine [6, p. 56-57].

Quantitative indicators of staffing the health care in Ukraine in 2014-2020

Table 1

\begin{tabular}{|l|c|c|c|c|c|c|c|}
\hline \multicolumn{1}{|c|}{ Number } & \multicolumn{5}{c|}{ Year } \\
\cline { 2 - 7 } & $\mathbf{2 0 1 4}$ & $\mathbf{2 0 1 5}$ & $\mathbf{2 0 1 6}$ & $\mathbf{2 0 1 7}$ & $\mathbf{2 0 1 8}$ & $\mathbf{2 0 1 9}$ & $\mathbf{2 0 2 0}$ \\
\hline $\begin{array}{l}\text { Total number of medical staff, } \\
\text { of them: }\end{array}$ & 564825 & 557970 & 553532 & 546594 & 531039 & 515035 & 488360 \\
\hline $\begin{array}{l}\text { 1) doctors in health care providers of all } \\
\text { forms of ownership, }\end{array}$ & 185945 & 186234 & 186776 & 186178 & 185675 & 184713 & 179602 \\
\hline $\begin{array}{l}\text { including doctors in private health } \\
\text { care providers; }\end{array}$ & 13549 & 14063 & 15504 & 16671 & 18844 & 20563 & 22382 \\
\hline $\begin{array}{l}\text { 2) middle medical staff in health care } \\
\text { providers all forms of ownership, }\end{array}$ & 378880 & 371736 & 366756 & 360416 & 345364 & 330322 & 308758 \\
\hline $\begin{array}{l}\text { including middle medical staff in } \\
\text { private health care providers }\end{array}$ & 11875 & 11862 & 12889 & 14239 & 16367 & 18754 & 20421 \\
\hline
\end{tabular}

Source: Based on the data of the statistical reference book of the Center for Medical Statistics of the Ministry of Health of Ukraine [7].

From 2016 to 2019, the number of working doctors in the health care sector decreased annually by an average of 688 person and the number of middle medical workers - by an average of 12.144 person. And in 2020, the reduction in the number of health workers reached a record high: -5.111 doctors and - 21.564 middle medical staff. We assume that such decline is caused by the COVID-19 pandemic.
Regarding the assessment of the density of medical staff in Ukraine on the whole and from the territorial aspect, we have the following indicators in 2020:

- there are 24.2 doctors per 10 thousand people in healthcare facilities (excluding managers and their deputies, dentists, statisticians, methodologists, etc.) [6, p. 23]. For comparison, according to the WHO, the quantity of doctors 


\section{N. Dochynets, O. Havrylets, H. Kampo}

per 10 thousand people in the European region is 34.1 [8];

- the lowest density of both practicing doctors and middle medical workers was observed in Donetsk, Mykolaiv, Kherson, Kyiv, and Zakarpattia regions [6, p. 23, 26];

- meanwhile, the highest density of practicing doctors and middle medical workers is observed in Ivano-Frankivsk, Ternopil, Lviv, Khmelnytsky, Vinnytsia, and Poltava regions [6, p. 23, 26].

In contrast to the Ukrainian trend towards decreasing number of doctors in OECD countries, there is a gradual increase in their number compared to 2000 , mainly due to the growth of university medical faculty graduates in these countries. That became possible because of government decisions to increase the enrollment of students in the relevant profile in response to the current shortage of doctors in most developed countries [3, p. 24].

In Ukraine, there is no balance between the increasing number of employees leaving the health care sector and the annual number of medical graduates. The reduction of human resources for health care and medical training has been observed since 2017 . The personnel reserve of medical students in Ukraine is no longer sufficient to replace the medical staff of retirement age. The ratio of medical school entrants and doctors of retirement age is about one to three, and the correlation between nursing school entrants and working middle medical staff retirees is one to four. [9, p. 5]. At the same time, the share of foreign students who receive higher medical education in medical specialties is growing every year. In 2018, the total number of foreign entrants to the medical school for the first time exceeded the number of Ukrainian entrants. As a result, the industry's staffing figures are likely to decline further.

The problem of staffing the market of medical services is exacerbated by external workforce migration. There are no official data on the number of Ukrainian doctors going abroad. However, it is well known that Ukraine has been an important provider of medical personnel for many EU countries for many years. Migration intensified in 2020 when in response to the COVID-19 pandemic, many European countries took steps to attract internationally trained medical professionals to meet the growing demand for health services.

Thus, the current state of staffing the health care sector in Ukraine is characterized by a constant decrease in the number of medical workers, respectively, and the number of practicing doctors and middle medical workers; reduction of medical training in higher education and postgraduate education institutions; uncontrolled processes of migration of medical workers from Ukraine to other countries. As a result, a shortage of staff in public health care facilities (at the end of 2020, the staffing of full-time medical positions by physicians was $81 \%$, middle medical workers $-88.5 \%$ ) is observed. [6, p. 56-57].

However, in the private sector, we can see the opposite trend. The number of medical workers involved in private healthcare clinics is constantly growing (Fig. 2).

Since 2014, the average increase in healthcare workers in private healthcare facilities has been 2.896 person per year (1.472 doctors and 1.424 middle medical workers). At the end of 2020, in total 42.803 health workers were employed in the private sector, which is almost $41 \%$ more than in 2014.

By the end of 2020, $12.5 \%$ of doctors (22.382) and $6.6 \%$ of middle medical workers (20.421) had been employed in the private sector. During 2010-2020, the proportion of staff working in the private sector more than doubled.

The analysis of staffing private medical institutions with doctors of different specialties shows that dentists and dermato-venereologists are most involved in the work here: at the end of 2020, $40 \%$ of all dentists (8.940 out of 22.180) worked in private healthcare institutions, about $21 \%$ of all dermatologists-venereologists (647 out of 3.127). Currently, psychiatrists and family doctors are the least involved in the private healthcare sector $1.5 \%$ and $2 \%$, respectively (Table 2 ).

In general, in private medical institutions, there is a tendency to increase the share of doctors of all specialties, except for oncologists (Fig. 3) 
On the problem of human resources in ukrainian private health care

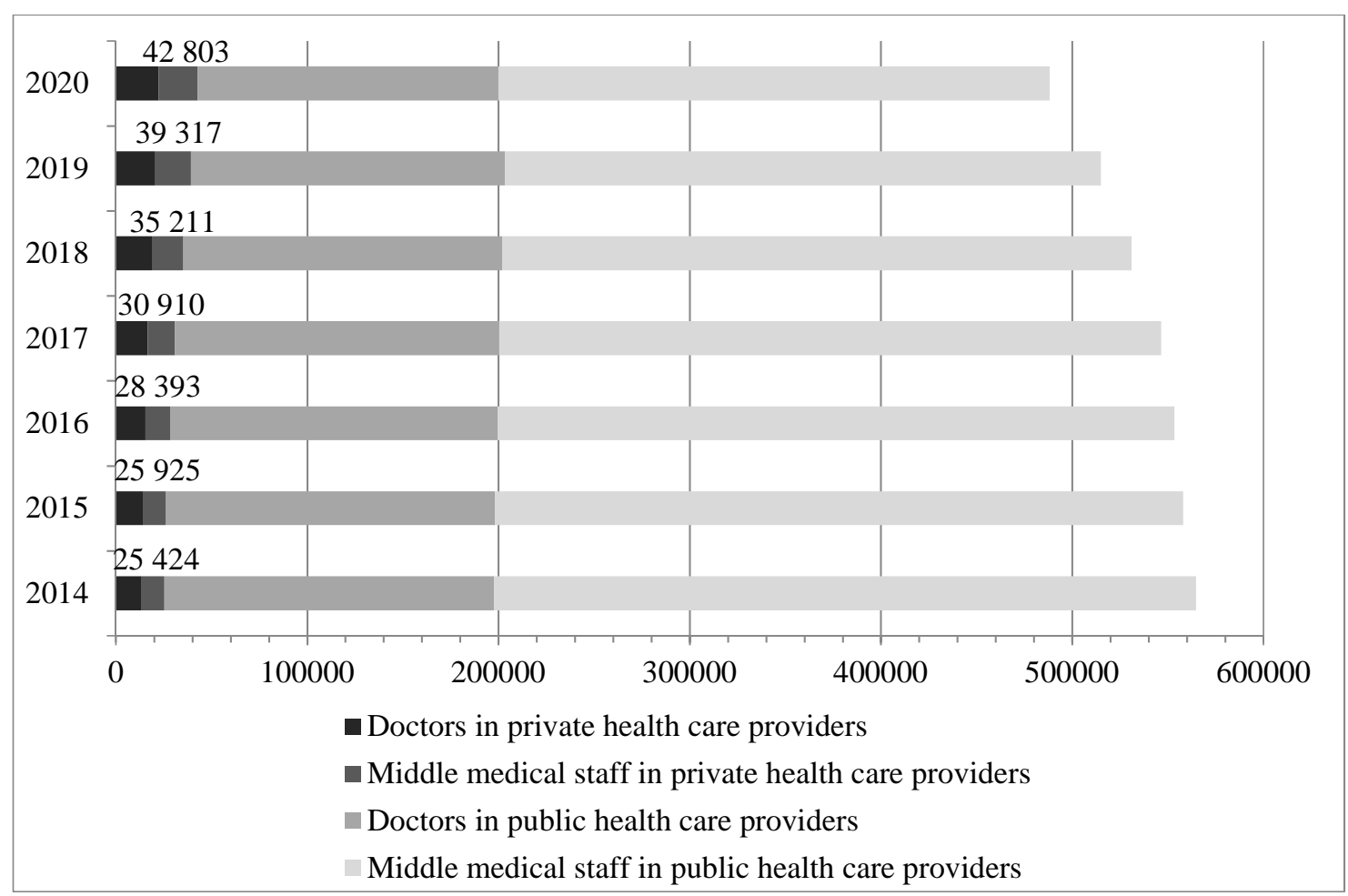

Fig. 2. Quantitative indicators of medical workers staffing in healthcare facilities of various forms of ownership in 2014-2020

Source: Based on the analysis of data of the statistical reference books of the Center for Medical Statistics of the Ministry of Health of Ukraine [7].

Table 2

Analysis of quantitative indicators of staffing the market of medical services by doctors of different specialties

\begin{tabular}{|l|c|c|c|c|c|c|}
\hline \multirow{2}{*}{ Specialty } & \multicolumn{2}{|c|}{ 2018 year } & \multicolumn{2}{c|}{ 2019 year } & \multicolumn{2}{c|}{ 2020 year } \\
\cline { 2 - 7 } & $\begin{array}{c}\text { in general in } \\
\text { healthcare } \\
\text { providers of all } \\
\text { forms of } \\
\text { ownership }\end{array}$ & $\begin{array}{c}\text { in private } \\
\text { healthcare } \\
\text { providers }\end{array}$ & $\begin{array}{c}\text { in general in } \\
\text { healthcare } \\
\text { providers of all } \\
\text { forms of } \\
\text { ownership }\end{array}$ & $\begin{array}{c}\text { in general in } \\
\text { in private } \\
\text { healthcare } \\
\text { providers }\end{array}$ & $\begin{array}{c}\text { providers of all } \\
\text { providers } \\
\text { forms of } \\
\text { ownership }\end{array}$ & $\begin{array}{c}\text { in private } \\
\text { healthcare } \\
\text { providers }\end{array}$ \\
\hline $\begin{array}{l}\text { Total number of } \\
\text { doctors, including: }\end{array}$ & 185675 & 18844 & 184713 & 20563 & 179602 & 22382 \\
\hline Psychiatrists & 3290 & 50 & 3211 & 47 & 3069 & 58 \\
\hline Family doctors & 15197 & 303 & 15576 & 456 & 15557 & 646 \\
\hline Surgeons (whole group) & 27652 & 1507 & 27854 & 1639 & 28363 & 2009 \\
\hline Pediatricians & 8981 & 544 & 8966 & 636 & 8812 & 698 \\
\hline Physicians (whole group) & 34960 & 2659 & 34455 & 2880 & 33551 & 3241 \\
\hline Oncologists & 835 & 86 & 809 & 79 & 1916 & 175 \\
\hline $\begin{array}{l}\text { Obstetricians - } \\
\text { gynecologists }\end{array}$ & 11398 & 1051 & 11248 & 1166 & 10871 & 1261 \\
\hline Dermato-venereologists & 3327 & 598 & 3276 & 605 & 3127 & 647 \\
\hline Dentists & 25651 & 8089 & 24622 & 8595 & 22180 & 8940 \\
\hline
\end{tabular}

Source: Based on the data of the statistical reference book of the Center for Medical Statistics of the Ministry of Health of Ukraine [6, p. 55]. 


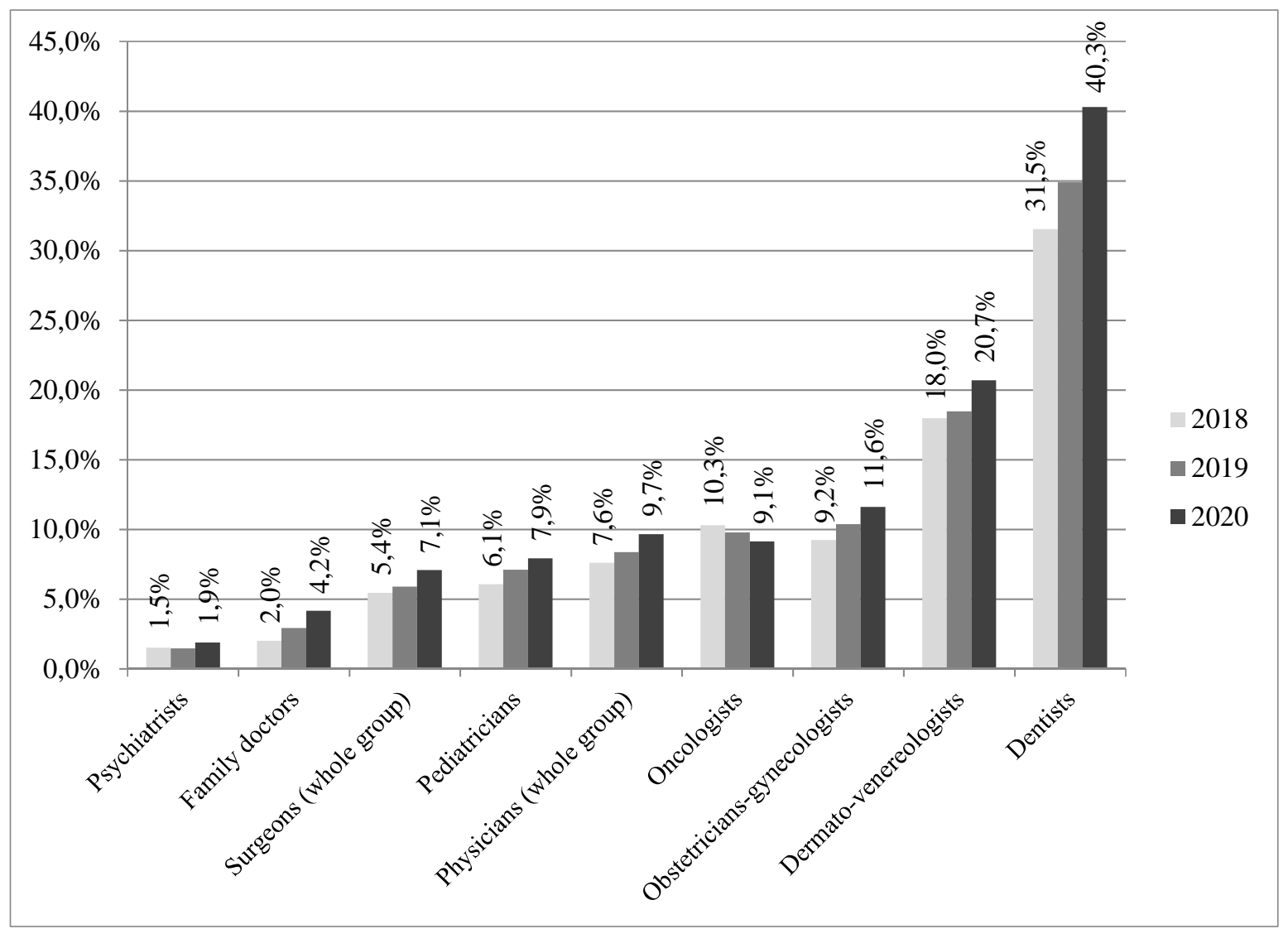

Fig. 3. Percentage of doctors working in private medical institutions in the total number of such professionals, 2016-2018

Source: Based on the analysis of data of the statistical reference books of the Center for Medical Statistics of the Ministry of Health of Ukraine [7].

The main problem of staffing health care is not the number of professionals but the quality of medical training. According to the results of our expert surveys, the heads of private institutions identify the quality of staff as a key factor in ensuring the competitiveness of health services. At the same time, they face insufficient satisfaction of the demand for medical staff, emphasizing the low general level of quality of professional knowledge of healthcare workers, which form the supply in the workforce market.

The international monitoring study of the quality of higher medical education, conducted in 2019 , confirmed the severity of the problem of the medical training quality. The study used the International Foundations of Medicine (IFOM) test, which measures competence in the basic sciences relevant to medical practice. The average result of the tested 4th-year students of the medical school of Ukraine is $26.6 \%$, while the international comparison group passed this test on average twice as well $-54 \%$ [10]. This result demonstrates a significant difference in approaches to the training of doctors in Ukraine and abroad, indicates the isolation of medical education from global trends. The competencies that students acquire are not always relevant due to the lack of international experience among the teaching staff and facilities necessary for effective preparation for the international component of the Unified State Qualification Exam.

It should be noted that the government is taking some systematic steps to solve the problem of the medical training quality in Ukraine. In 2016, following the Strategy for the Development of Medical Education in Ukraine, medical education, science, and human resources development policy was evolved. So, as a result:

- new increased admission requirements for entrants to medical schools have been established; 


\section{On the problem of human resources in ukrainian private health care}

- under the best international practices, a new type of comprehensive attestation of medical students has been introduced - a unified state qualification exam, which includes not only a test of theoretical knowledge but also a practical exam, an international exam in medicine, and an English language exam; the bases of the introduction of doctors professional licensing are evolved;

- a new model of continuous professional development of medical workers was introduced, which, particularly, provides the requirement of mandatory training with a set of at least 50 BPD points per year, the abolition of the procedure of "certification";

- a new model of ordering and internship has been developed, according to which internship enrollment will take place by electronic distribution and will depend on the graduate's rating score and his priority applications, regardless of the form of payment (contract or budget) for training.

In our opinion, one more advanced act was realized to improve the staffing of private healthcare clinics. Thus, in 2018, the Ministry of Health of Ukraine changed its approach to healthcare facilities management, taking into account that clinical competence and manager competence differ significantly. By order of the Ministry of Health of Ukraine № 1977 of October 31, 2018, changes were made to the National Classification of Occupations regarding the separation of functions of a director and medical director in a health care institution: the director of the institution is responsible for economic activities, and the medical director (chief physician) - only medical questions. We should remind that the profession of health care manager has not been singled out in Ukraine so far, and only medical doctors could become health care managers. It reduced the effectiveness of healthcare management.

It is too early to talk about the effectiveness of measures to improve the staffing of the medical services market. At present, Ukraine ranks 38th in the European region by the level of medical staff supply and is twice as low by the level of physicians supply in countries such as Slovakia, Hungary, Norway, and Italy [3].

\section{Conclusions and prospects for further research}

Thus, according to the results of the study of the human resources supply in health care of Ukraine, we state the presence of crisis phenomena, which not only reduces the competitiveness of the industry but also seriously threatens its viability. The general decrease in the quantitative indicators of staffing the healthcare system is due to the withdrawal from the national market of employees of public medical facilities. The private sector, on the other hand, is characterized by a steady increase in these indicators. However, the issue of the staff professional training quality remains acute, despite the government measures to improve medical education, science, and human resources.

In this regard, the state's efforts to staff private healthcare providers (as well as the industry in general), of course, should be strengthened to improve the quality of medical training. It is necessary to improve the internship procedure, which is excessively bureaucratic, non-transparent, and inefficient for staff motivation. Also, a new system of continuous professional development needs improvement (annual set of points due to formal or informal education) because it has no guaranteed funding. That's why doctors have to pay for training themselves, which is hardly affordable. The requirements for providers and contents of training programs should be improved, as well as the search the way to prevent falsifications during the professional training. Also, we need to increase the prestige of medical professions in society.

Given the European integration vector of Ukraine's development, it needs further research on human resources in health care using a comparative analysis of staffing the national health care system (the private and other sectors) with the workforce supply of the industry in the EU. But, as the national system of accounting of medical personnel overestimates the indicators of staffing because it includes specialties that are not taken into account according to the international classification. So, it is important to harmonize national statistical reporting with international standards ISCO-2008, which will simplify the comparison of Ukrainian data on 


\section{N. Dochynets, O. Havrylets, H. Kampo}

human resources with other countries and ensure the validity and reliability of research results.

\section{References}

1. Lehan I., \& Krykun O. (2020). Private medicine market of ukraine: features of regulation and directions of development Halytskyi ekonomichnyi visnyk, 3 (64), 192-197 [in Ukrainian]. https://doi.org/ 10.33108/galicianvisnyk_tntu2020.03.192

2. Hutsaliuk O. M. (2019). Analysis of the state of staffing health care in Ukraine during the reform period. Bulletin of Economic Science of Ukraine, 2 (37), 110--114. [in Ukrainian].

3. Volosovets O. P., Zabolotko V. M., \& Volosovets A. O. (2020). Staffing the health care sector in Ukraine and in the world: modern challenges. Ukrainian Medical News, Vol. 12, 1(84), 20-26. [in Ukrainian].

4. Mazur I. P., Nadutyi K. O., \& Ananieva A. V. (2020). Medical personnel of Ukraine: analysis for 2018. Health of Ukraine of the 21st century, №2 (471), 22-24. [in Ukrainian].

5. Limeshko O. (2019). Medical staff: features of selection in Ukraine. Retrieved from https://uteka.ua/ua/publication/knp-26-oplata- truda-i-kardovyi-uchet-84-medicinskij-personalosobennosti-podbora-v-ukraine. [in Ukrainian].

6. Zabolotko V. M, Steshenko I. E, Yevdokimenko O. A., Kharkevych L. B. (2021). Medical staff and network of health care facilities of the Ministry of Health of Ukraine for 2019-2020. Statistical reference book of the State Enterprise "Center for Medical Statistics of the Ministry of Health of Ukraine", Kyiv, 64 p. [in Ukrainian].

7. Statistical reference books for 2014-2020. Website of the State Institution "Center for Medical Statistics of the Ministry of Health of Ukraine". Retrieved from http://medstat.gov.ua/ukr/statdov_r.html. [in Ukrainian].

8. World Health Organization (2020). World health statistics 2020: monitoring health for the SDGs, sustainable development goals. Geneva: Licence: CC BY-NC-SA 3.0 IGO.

9. Bohdan D, Boiko A., \& Vasylkova A. et al. (2019). Human resources of the health care system in Ukraine. Situation Analysis. USAID Health Care Support Project. Kyiv. [in Ukrainian].

10. Ministry of Health of Ukraine: What was, is and will be. Retrieved from https://moz.gov.ua/uploads/2/ 13773-transition_book_healthcare.pdf. [in Ukrainian]. 